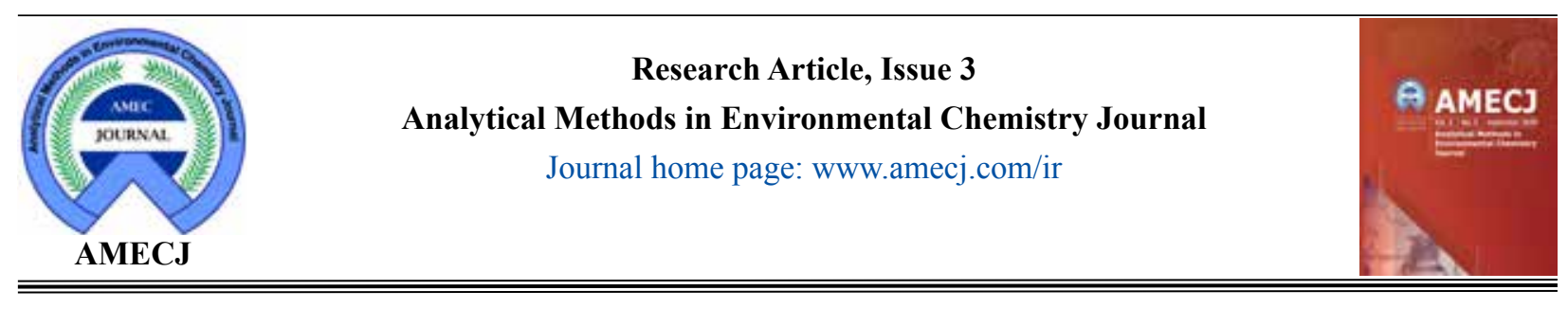

\title{
Speciation of selenium (IV, VI) in urine and serum of thyroid patients by ultrasound-assisted dispersive liquid-liquid microextraction
}

\author{
Elham Mosafayian Jahromy a and Negar Motakef Kazemi ${ }^{\text {a,* }}$ \\ ${ }^{a}$ Department of Medical Nanotechnology, Faculty of Advanced Sciences and Technology, Tehran Medical Sciences, \\ Islamic Azad University, Tehran, Iran
}

\section{A R T I C L E I N F O : \\ Received 22 May 2020 \\ Revised form 17 Jul 2020 \\ Accepted 11 Aug 2020 \\ Available online 26 Sep 2020}

Keywords:

Selenium,

Inorganic speciation,

Serum and urine,

Isopropyl [(IsopropoxyCarbothiolyl)

Disulfanyl] Ethane Thioate,

Ultrasound-assisted dispersive liquid-

liquid bio-microextraction,

\begin{abstract}
A B S T R A C T
In-vitro speciation of inorganic selenium $\left(\mathrm{Se}^{\mathrm{IV}}\right.$ and $\left.\mathrm{Se}^{\mathrm{VI}}\right)$ in serum blood and urine of hyperthyroidism and hypothyroidism patients based on isopropyl 2-[(isopropoxycarbothiolyl) disulfanyl] ethane thioate (IICDET) as a complexing agent were studied by ultrasoundassisted dispersive liquid-liquid bio-microextraction procedure (USADLLMBE). In first stage, $100 \mu \mathrm{L}(\approx 0.1 \mathrm{~g})$ of hydrophobic ionic liquid of $\left[\mathrm{C}_{8} \mathrm{MIM}\right]\left[\mathrm{PF}_{6}\right]$ mixed with IICDET ligand and $100 \mu \mathrm{L}$ of acetone. Then, the mixture injected to $10 \mathrm{~mL}$ of human samples at $\mathrm{pH}=4$. After shacking, the Se (IV) ions were complexed by IICDET and extracted to IL at $\mathrm{pH}=4$ (R-S: ...Se). The IL phase was separated from sample by centrifuging and inorganic selenium $\left(\mathrm{Se}_{\mathrm{IV}}\right)$ in remained samples was determined by electro thermal atomic absorption spectrometry (ET-AAS) after back extraction of Se (IV). As speciation, the Se (VI) reduced to $\mathrm{Se}(\mathrm{IV})$ in acidic $\mathrm{pH}\left(\mathrm{HCl}, 130^{\circ} \mathrm{C}\right)$ and the total $\mathrm{Se}(\mathrm{T}-$ $\mathrm{Se})$ was obtained at $\mathrm{pH}=4$. Therefore, the $\mathrm{Se}(\mathrm{VI})$ was calculated by difference of T-Se and Se (IV). After optimized conditions, the enrichment factor (EF), Linear range and limit of detection (LOD) for inorganic Se (IV) were obtained 20.1, 0.75- $20 \mu \mathrm{g} \mathrm{L}^{-1}$ and 0.18 $\mu \mathrm{g} \mathrm{L}^{-1}$ in serum and urine samples respectively. The results showed us, the concentration of selenium was decreased in thyroid patients as compared to healthy peoples. The validation of methodology was achieved by certified reference material (CRM) and ICP-MS.
\end{abstract}

\section{Introduction}

Selenium is an essential trace element in humans. The soluble selenium compounds can be easily absorbed through the lungs and the gastrointestinal tract. Selenium is mainly excreted in human urine [1]. When the exposure is very high it can also be excreted in exhaled air as dimethylselenide vapor (DMSe). Normal selenium concentrations in serum

\footnotetext{
*Corresponding Author: Negar Motakef Kazemi

Email: negar.motakef@gmail.com
}

https://doi.org/10.24200/amecj.v3.i03.109 and urine are dependent on daily intake, which may vary considerably in different parts of the world but are usually below $15 \mu \mathrm{g}$ per $100 \mathrm{~mL}^{-1}$ and $25 \mu \mathrm{g}$ $\mathrm{g}^{-1}$ creatinine, respectively [2-5]. The concentration of selenium in urine is mainly a reflection of recent exposure. The relationship between the intensity of exposure and selenium concentration in urine has not been established yet. It seems that the concentration in plasma (or serum) and urine mainly reflects to short-term exposure, whereas the selenium content of erythrocytes reflects more long-term exposure 
[6]. Measuring selenium in blood or urine gives some information on selenium status. Currently it is more often used to detect a deficiency rather than an overexposure. Since the available data concerning the health risk of long-term exposure to selenium and the relationship between potential health risk and levels in biological media are too limited. So, the biological threshold value for Se wasn't reported [7]. The thyroid is the organ with the highest selenium content per gram of tissue because it expresses specific selenoproteins. The value of selenium supplementation in autoimmune thyroid disorders has been emphasized. Most authors attribute the effect of supplementation on the immune system to the regulation of the production of reactive oxygen species and their metabolites [8-10]. The mechanism and role of selenium in inflammation, immunity and hepatocytes was reported [11, 12] In patients with Hashimoto's disease and in pregnant women with anti-TPO antibodies, selenium supplementation decreases antithyroid antibody levels and improves the ultrasound structure of the thyroid gland [13]. Although clinical applications still need to be defined for Hashimoto's disease, they are very interesting for pregnant women given that supplementation significantly decreases the percentage of postpartum thyroiditis and definitive hypothyroidism. In Graves' disease, selenium supplementation results in euthyroidism being achieved more rapidly and appears to have a beneficial effect on mild inflammatory orbitopathy [14]. A risk of diabetes has been reported following long-term selenium supplementation, but few data are available on the side effects associated with such supplementation and further studies are required. One of the diseases that affect the thyroid gland is subclinical hypothyroidism, which is characterized by elevated serum levels of thyroid-stimulating hormone (TSH) at a concentration recommended for prohormone thyroxine (T4) and active hormone triiodothyronine (T3). The decompensated levels of thyroid hormones may contribute to atherosclerotic events and an increase in cardiovascular-related mortality [15]. Also, observational longitudinal studies have shown an inverse association between selenium exposure and risk of some cancer types but still to be confirmed [16]. It is estimated that subclinical hypothyroidism affects $3-8 \%$ of the general population and is more common in women than in men. In Brazil, an epidemiological study in elderly reported that prevalence of subclinical hypothyroidism was $6.5 \%$. The thyroid gland contains high levels of selenium (Se) and expresses a variety of selenoproteins that are involved in protection of oxidative stress and metabolism of thyroid hormones (TH) [17]. Selenium deficiency impairs regular synthesis of selenoproteins and adequate $\mathrm{TH}$ metabolism. Therefore selenium species in serum and urine must be evaluated and determined by favorite techniques. The different methods such as, flame atomic absorption spectrometry [18], electrothermal atomic absorption spectrometry [19], liquid chromatography and liquid chromatography inductively coupled plasma mass spectrometry (LC and LC-ICP- MS) [20-22] and high-performance liquid chromatography coupled to hydride generation atomic fluorescence spectrometry $[23,24]$ were used for Se determination in different human and water samples. A sample preparation is required to extract metals ions in different biological samples. The sample preparation such as microextraction techniques [25], suspended dispersive solid phase microextraction [26], ultrasonic assisted dispersive liquid-liquid microextraction method [27] and ultrasound assistedionic liquid-solid phase microextraction [28] were used for extraction metals in human samples. In this study, the mixture of hydrophobic ionic liquid of $\left[\mathrm{C}_{8} \mathrm{MIM}\right]$ $\left[\mathrm{PF}_{6}\right]$, IICDET ligand and acetone was used for selenium speciation /extraction based on ultrasoundassisted dispersive liquid-liquid bio-microextraction procedure (USA-DLLMBE) and determined by ETAAS. The Se (IV) ions were complexed by IICDET and extracted to IL at $\mathrm{pH}=4$. Then speciation of $\mathrm{Se}$ was obtained by total determination of selenium. Validation methodology was confirmed by spiking of standard samples and ICP-MS.

\section{Experimental}

\subsection{Instrument and Reagents}

The electrothermal atomic absorption spectrophotometer(ET-AAS, GBC932plus,Australia) 
equipped with a graphite furnace (Pal GF3000) were used for the validation and determination of selenium (Se) in samples (Wavelength $349.9 \mathrm{~nm}$; slit $0.2 \mathrm{~nm}$; current $10 \mathrm{~mA}$ ). The working range as peak area and height was obtained 15- $400 \mu \mathrm{g} \mathrm{L}-1$ and 15-210 $\mu \mathrm{g} \mathrm{L}^{-1}$, respectively. The linear range was achieved for peak area of $0.3 \mathrm{Abs}$ for sample injection. Based on the manual book of ET-AAS, the Se determination was achieved by injecting $20 \mu \mathrm{L}$ of sample to graphite tube with auto-sampler in three steps of drying, ashing, and atomization for Se. The ICP-MS (Perkin Elmer, USA) as ultra-trace analysis with high sensitivity was used for determining of $\mathrm{Se}(\mathrm{IV})$ and $\mathrm{Se}(\mathrm{VI})$ in human blood and water samples $\left(1100 \mathrm{~W} ; 15 \mathrm{~L} \mathrm{~min}^{-1} ; 1.5 \mathrm{sec}\right.$ per mass; auxiliary gas $\left.1.12 \mathrm{~L} \mathrm{~min}^{-1}\right)$. The Metrohm $\mathrm{pH}$ meter based on the glass electrode was used for measuring $\mathrm{pH}$ in serum, urine and blood samples (E-744, Switzerland). The vortex mixer were used for shaking of human samples based on $300 \mathrm{rpm}$ speeds and centrifuged by Falcon accessory by 4000 rpm speeds (Thermo, USA). An ultrasonic bath was used for blood and urine samples with heat controller between $30-120^{\circ} \mathrm{C}$ (Thomas, USA). The standard solution of Se (VI, VI) was purchased from Merck CO. (Germany) with a concentration of $1000 \mathrm{mg} \mathrm{L}^{-1}$ in $1 \% \mathrm{HNO}_{3}$. The different concentration of Selenium was prepared by dilution of deionized water (DW) and ultrapure water was purchased from Millipore Company. The 1-Hexyl-3-methylimidazolium hexafluorophosphate as hydrophobic ionic liquid was purchased from Sigma Aldrich ([HMIM] $\left[\mathrm{PF}_{6}\right], \mathrm{CAS}$ $\mathrm{N}$ : 304680-35). Isopropyl 2-[(isopropoxycarbothioyl) disulfanyl] ethane thioate was synthesized and purified by Azad university laboratories (IICDET; $(\mathrm{CH} 3)_{4}$ (CO) $\left.)_{2} \mathrm{~S}_{4}\right)$. The acetate $\left(\mathrm{CH}_{3} \mathrm{COOH} / \mathrm{CH}_{3} \mathrm{COONa}\right)$ and phosphate buffer was used to adjust the $\mathrm{pH}$ between 2.8-6.2 and 6.2-8.2, respectively. The analytical grade of reagents such as polyoxyethylene octyl phenyl ether (TX-100) as the anti-sticking agent, $\mathrm{HNO}_{3}, \mathrm{HCl}$, acetone, and ethanol were purchased from Sigma Aldrich, Germany.

\subsection{Preparation of human samples}

All glass or PCV tubes were cleaned with a 1.0 mol L-1 $\mathrm{HNO}_{3}$ solution for at least one day and then washed for ten times with ultrapure water. As low concentrations of $\mathrm{Se}(\mathrm{IV})$ and $\mathrm{Se}(\mathrm{VI})$ in human serum, blood and urine samples, the cations or anions contamination at any stage of sample preparation, saving and analytical processes can be affected on the results accuracy. Heparin was used as anticoagulants for human blood samples into Eppendorf $(5 \mathrm{~mL})$ tubes and kept at $-20^{\circ} \mathrm{C}$ for two weeks. Each blood samples were prepared by 10 $\mu \mathrm{L}$ of pure heparin (free $\mathrm{Se}$ ) to blood sample. The serum, blood and urine samples were collected from hypothyroidism patients (50) and healthy peoples (50) with aged between 25 - 60 years, Tehran (IRAN). In this study, the world medical association declaration of Helsinki (WMADH) based on guiding physicians in human body research was considered by project of Azad university (AZAD UN. SPN: 960250673). The human samples were prepared based on WMADH law and absolutely protected the life and health of the human subject.

\subsection{Synthesis of IICDET ligand}

The $2.0 \times 10^{-3} \mathrm{~mol}$ of potassium O-isopropyl (ditiocarbomate) was dissolved in $20 \mathrm{~mL}$ of $\mathrm{DW}$ and cooled in an ice bath for 10 minutes. The $2.0 \times 10^{-3} \mathrm{~mol}$ of iodine solution and potassium iodide as drop wise was added to $20 \mathrm{ml}$ of DW. After stirring of mixture for $1 \mathrm{~h}$, the aqueous phase was extracted with $\mathrm{CH}_{2} \mathrm{Cl}_{2}$ and washed with $30 \mathrm{~mL}$ of aqueous $\mathrm{Na}_{2} \mathrm{~S}_{2} \mathrm{O}_{3}(10 \%)$ and $\mathrm{DW}$. The organic phase was dried and evaporated with powder anhydrous calcium chloride $\mathrm{Ca} \mathrm{Cl}_{2}$ (99.99\%; CAS Number: 10043-52-4). The purification was obtained by recrystallization in hexane. A pale yellowish crystal of isopropyl 2-[(isopropoxycarbothiolyl) disulfanyl] ethane thioate with a yield of $95 \%$ was achieved. The structure and isopropyl 2-[(isopropoxycarbothiolyl) disulfanyl] ethane thioate were confirmed by NMR spectroscopic methods (Fig. 1). ${ }^{1} \mathrm{H} \mathrm{NMR}\left(\mathrm{CDCl}_{3}\right)$. $\delta(\mathrm{ppm}): 1.43\left(\mathrm{~d}, 12 \mathrm{H}, \mathrm{CH}_{3}\right), 5.63(\mathrm{~m}, 2 \mathrm{H}, \mathrm{CH})$. ${ }^{13} \mathrm{C} \mathrm{NMR}\left(\mathrm{CDCl}_{3}\right) . \delta$ (ppm): 22.2, 80.6, 207.1. IR (KBr). vmax (cm-1): 2979.8 (s), 2869.9 (w), 1463.9 (s), 1442.7 (s), 1373.0 (s), 1271.1 (s, b), $1145.6(\mathrm{~s}), 1082.2(\mathrm{~s}), 1048.0(\mathrm{~s}, \mathrm{~b}) 898.8(\mathrm{~s}), 796$. $5(\mathrm{~s}), 690.5(\mathrm{~m})$. 


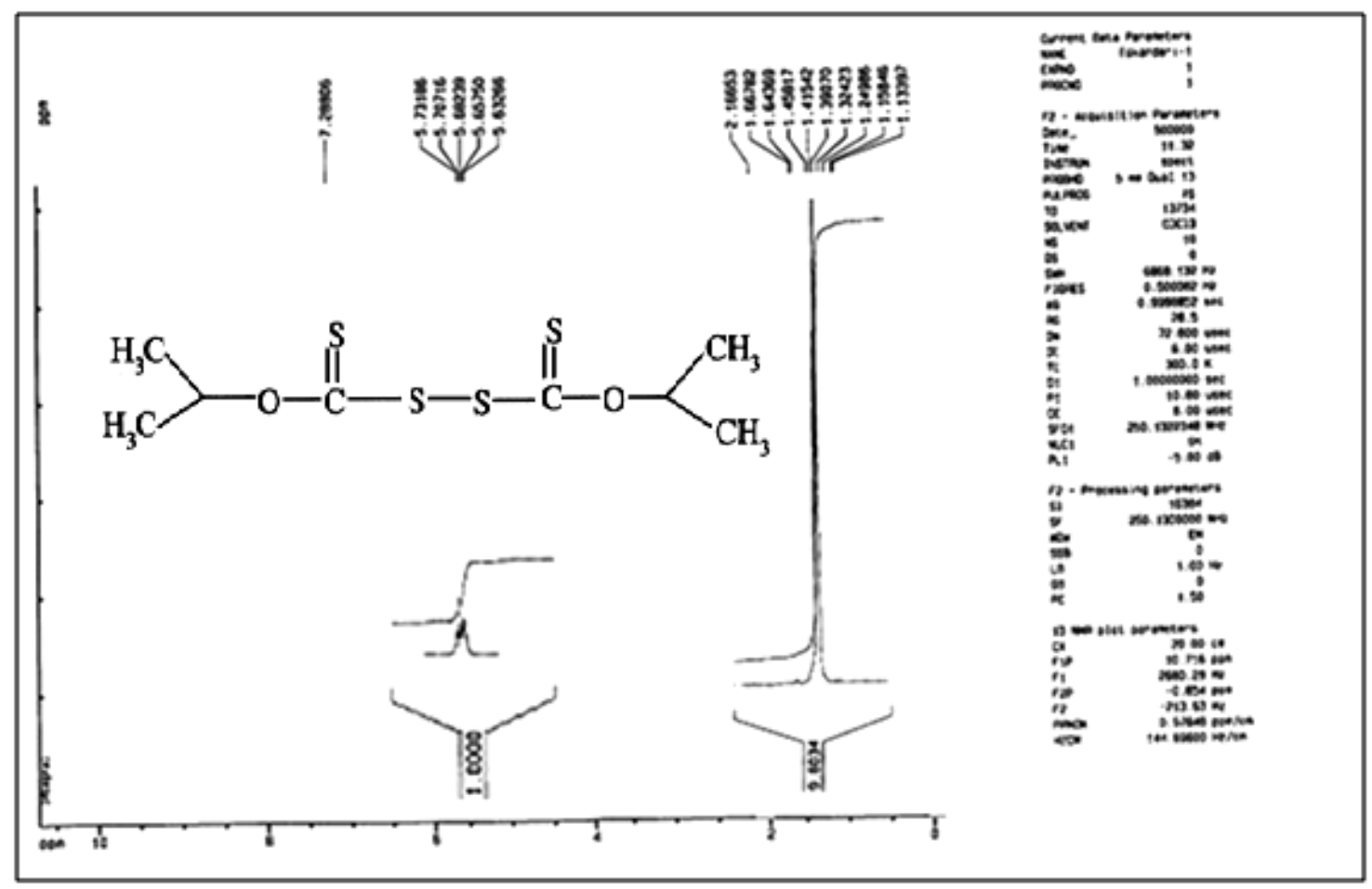

Fig.1. NMR spectroscopic for isopropyl 2-[(isopropoxycarbothiolyl) disulfanyl] ethane thioate

\subsection{Extraction Procedure}

The Se (IV) based on IICDET ligand was extracted by ultrasound-assisted dispersive liquid-liquid biomicroextraction procedure (USA-DLLMBE). By procedure, $100 \mu \mathrm{L}(\approx 0.1 \mathrm{~g})$ of hydrophobic ionic liquid of $\left[\mathrm{C}_{8} \mathrm{MIM}\right]\left[\mathrm{PF}_{6}\right]$ mixed with $0.35 \times 10^{-6} \mathrm{~mol}$ $\mathrm{L}^{-1}$ of IICDET solution and $100 \mu \mathrm{L}$ of acetone at $\mathrm{pH}$ of 4 . The mixture based on Triton X-100, an emulsifier and anti-sticking agent was injected to 5 $\mathrm{mL}$ of blood, serum and urine samples which was diluted with $5 \mathrm{~mL}$ of DW. For optimizing, $1.0 \mu \mathrm{g}$ $\mathrm{L}^{-1}$ and $20 \mu \mathrm{g} \mathrm{L} \mathrm{L}^{-1}$ of standard solution of Se (IV) as LLOQ and ULOQ was used instead of the blood and serum samples. After shacking, the Se (IV) ions were complexed by IICDET and extracted to IL at $\mathrm{pH}=4$ (R-S: ...Se). By centrifuging (3 $\mathrm{min})$, the IL phase was separated from sample and inorganic selenium ( $\mathrm{Se}_{\text {IV }}$ ) was back- extracted from IL phase in basic $\mathrm{pH}(0.25 \mathrm{~mL}$ of $1.0 \mathrm{~mol}$ $\left.\mathrm{L}^{-1} \mathrm{NaOH}\right)$. Finally, the remained samples was determined by electro thermal atomic absorption spectrometry (ET-AAS), the Se (VI) reduced to Se
(IV) in acidic $\mathrm{pH}\left(\mathrm{HCl}, 130^{\circ} \mathrm{C}\right)$ and the total $\mathrm{Se}(\mathrm{T}-$ $\mathrm{Se}$ ) was obtained at $\mathrm{pH}=4$. Therefore, the $\mathrm{Se}$ (VI) was calculated by difference of T-Se and Se (IV) amount (Fig.2).

\section{Results and Discussion}

The human blood, serum and urine samples based on IICDET was used for selenium speciation with high accuracy by USA-DLLMBE procedure. The results showed us, the mean concentrations of Se (IV and VI) in human biological samples in hypothyroidism patients (50) were significantly higher than the healthy peoples (50). As linear range of selenium between $0.75-20 \mu \mathrm{g} \mathrm{L}^{-1}$, the human samples can be diluted before using by proposed procedure. Based on results, the mean concentration of total selenium in urine and serum of hypothyroidism patients was obtained $11.8 \mu \mathrm{g}$ $\mathrm{g}^{-1}$ creatinine and $52.6 \mu \mathrm{g} \mathrm{L}^{-1}$, respectively which was less than $25 \mu \mathrm{g} \mathrm{g}^{-1}$ creatinine for urine samples and $150 \mu \mathrm{g} \mathrm{L}^{-1}$ for serum samples as TLVs in standard references. 


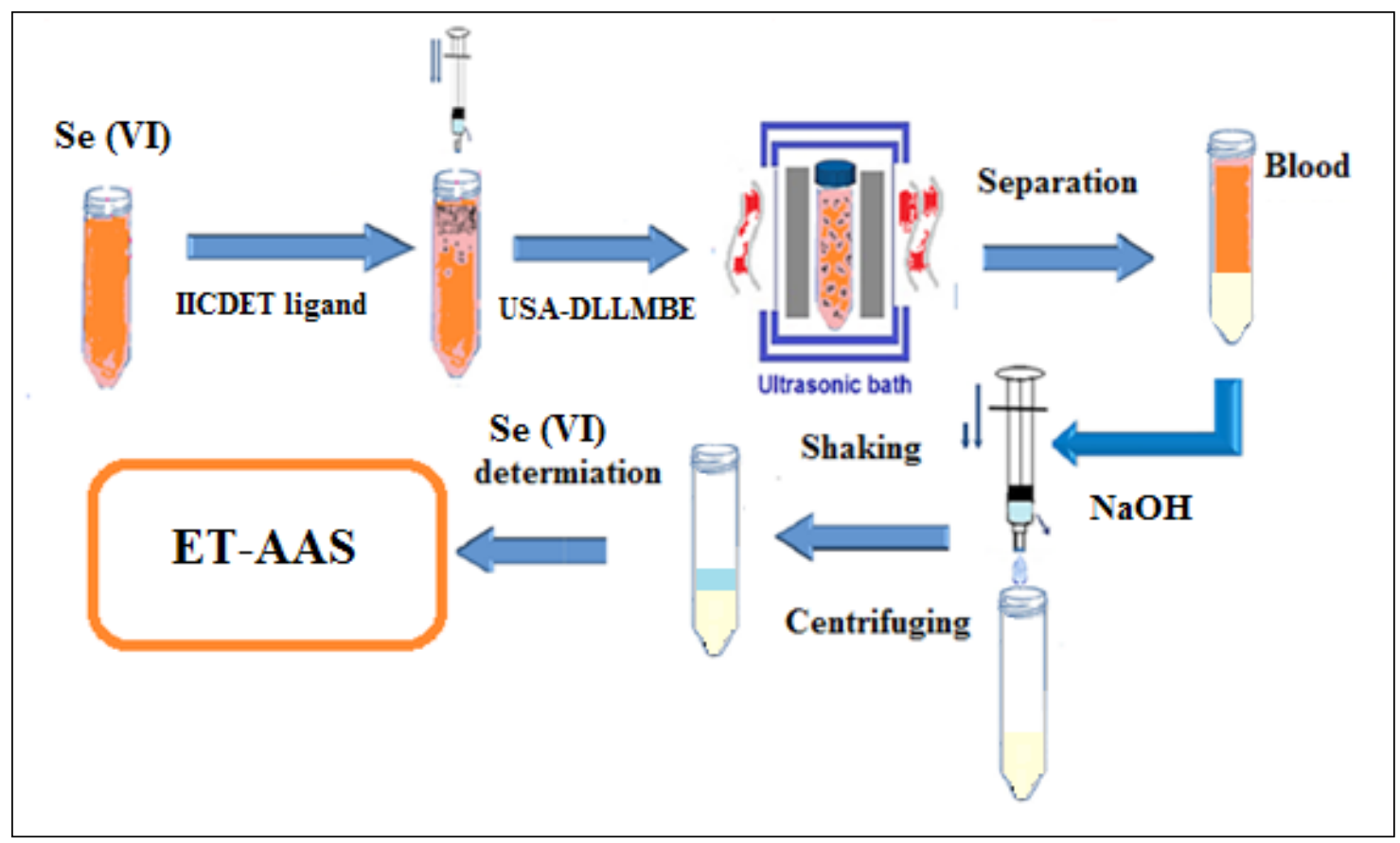

Fig. 2. Separation of selenium (IV) by ultrasound-assisted dispersive liquid-liquid bio-microextraction procedure (USA-DLLMBE)

\subsection{Effect of ETAAS}

The effect of pyrolysis temperature on the absorbance of Se was studied up to $1000{ }^{\circ} \mathrm{C}$. The maximum absorbance was achieved within a range of $600-800{ }^{\circ} \mathrm{C}$. Therefore, $700{ }^{\circ} \mathrm{C}$ was selected as the working pyrolysis temperature for selenium by nickel nitrate as modifier at concentration of 0.05 to $0.1 \% \mathrm{Ni}$. In addition, a drying as a $25 \mathrm{~s}$ was chosen for water evaporation, and a long ramp time of 40 $\mathrm{S}$ was chosen as it allowed gradual elimination of trace ionic liquid solution in liquid phase $\left(350^{\circ} \mathrm{C}\right)$ and avoided Se loss in pyrolysis temperature. The effect of atomization temperature on chromium signal was studied within the range of 2000-2500 ${ }^{\circ} \mathrm{C}$, and the maximum signal was obtained at approx. $2400{ }^{\circ} \mathrm{C}$. Cleaning time and temperature were ordered at $2 \mathrm{~s}$ and $2500{ }^{\circ} \mathrm{C}$, respectively, and argon flow rate was $350 \mathrm{~mL} \mathrm{~min}^{-1}$

\subsection{Optimization of $p H$}

The sample $\mathrm{pH}$ for extraction Se(IV) ions based on IICDET ligand was studied and optimized in different $\mathrm{pH}$ ranges between $2-11$ for $0.75 \mu \mathrm{g} \mathrm{L}^{-1}$ as a lower limit of quantification (LLOQ) and 20 $\mu \mathrm{g} \mathrm{L}^{-1}$ selenium as upper limit of quantification (ULOQ). The complexation Se with sulfur of IICDET ligand was strongly depended on the $\mathrm{pH}$ of serum, blood and urine samples and caused to increase the recovery of extraction by ligand. Based on experimental results, the extraction efficiency of $\mathrm{Se}(\mathrm{IV})$ ions was perfectly achieved at $\mathrm{pH}=3.5$ 4.5. Therefore, the USA-DLLMBE procedure was used to speciation of selenium at $\mathrm{pH}=4$ by IICDET ligand. The mechanism of Se extraction was obtained based on the complex formation of IICDET ligand between Se(IV) ions and sulfur covalence bonding of IICDET at optimized $\mathrm{pH}$. The sulfur groups can be deprotonated $\left(\mathrm{SH}^{-}\right)$at $\mathrm{pH}$ range of 3.5-8 and $\mathrm{pH}=4$ was used as favorite $\mathrm{pH}$ for extraction of $\mathrm{Se}(\mathrm{IV})$ from human biological samples which was shown in Figure 3. As hydroxyl form of $\mathrm{Se}(\mathrm{OH})_{4}$ in above $\mathrm{pH}$ (more than 6), the extraction capacity of $\mathrm{Se}(\mathrm{IV})$ in basic $\mathrm{pH}$ may be attributed to the affinities of $\mathrm{OH}$ groups. 


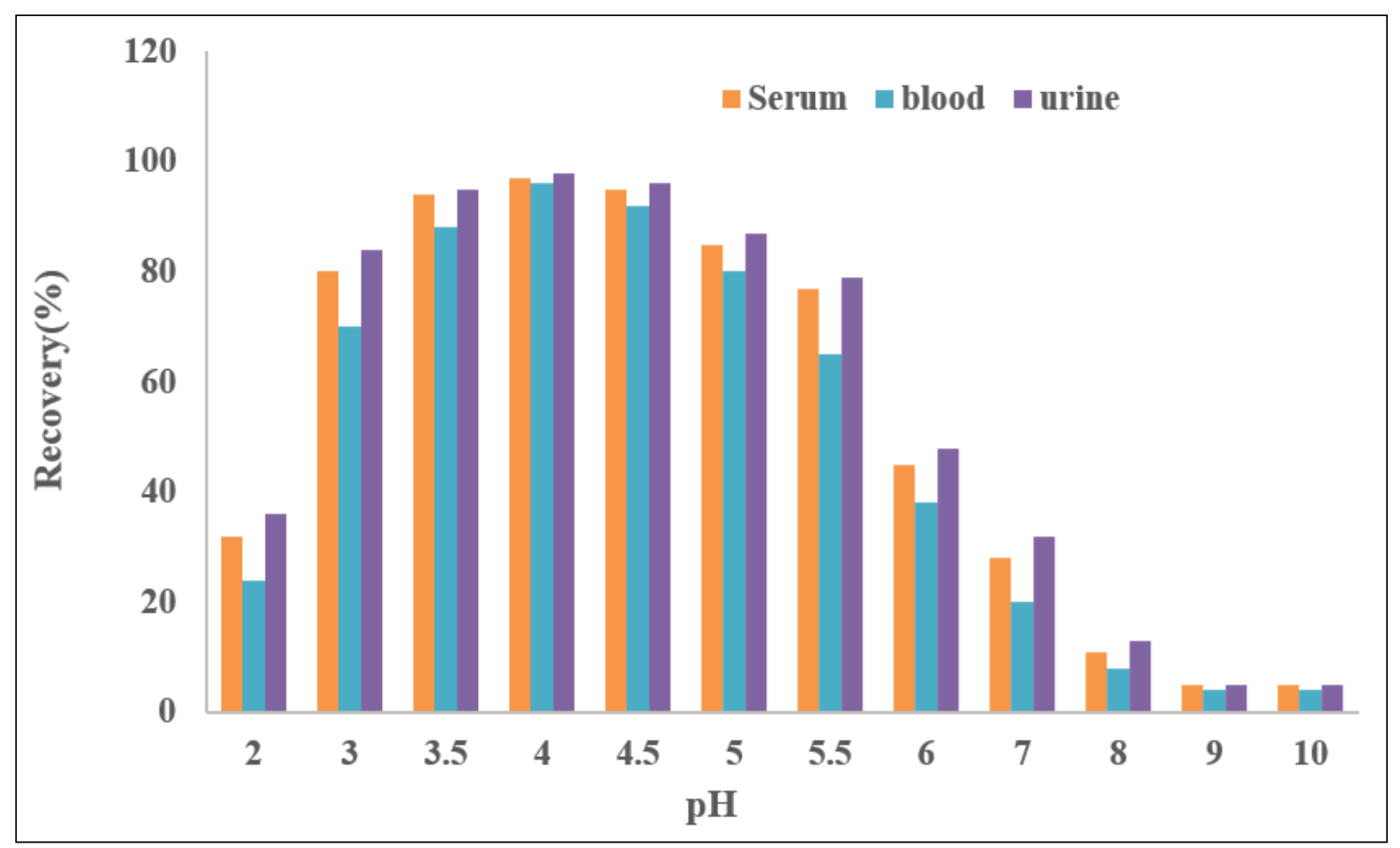

Fig.3. The effect of $\mathrm{pH}$ on Extraction Se(IV) based on IICDET ligand by USA-DLLMBE procedure

\subsection{Optimization of IICDET ligand}

The concentration of IICDET ligand as important parameters must be studied and optimized by USA-DLLMBE procedure. For optimizing, the concentration of $0.1 \times 10^{-6}-1.0 \times 10^{-6} \mathrm{~mol} \mathrm{~L}^{-1}$ of IICDET ligand was used for evaluation. Due to results, the more concentration of $0.33 \times 10^{-6}$ mol L $\mathrm{L}^{-1}$ of IICDET, has no effect on recoveries. So, the concentration of $0.35 \times 10^{-6} \mathrm{~mol} \mathrm{~L}^{-1}$ of IICDET was selected as optimum ligand concentration for high extraction efficiency. The signal remained constant from $0.35 \times 10^{-6}$ mol L-1 up to at least $1.0 \times 10^{-6} \mathrm{~mol} \mathrm{~L}^{-1}$ IICDET for $0.75 \mu \mathrm{g} \mathrm{L}^{-1} \mathrm{Se}$ as a LLOQ range Therefore $0.35 \times 10^{-6} \mathrm{~mol} \mathrm{~L}^{-1}$ of IICDET concentration was used for further works. As $20 \mu \mathrm{g} \mathrm{L}^{-1}$ of Se as a ULOQ range, the signal remained constant from $0.4 \times 10^{-6} \mathrm{~mol} \mathrm{~L}^{-1}$ up to at least $1.0 \times 10^{-6}$ mol L $\mathrm{L}^{-1}$ and $0.4 \times 10^{-6} \mathrm{~mol} \mathrm{~L}^{-1}$ was selected as an optimized IICDET concentration. By adjusting $\mathrm{pH}$, the best performance of the $\mathrm{Se}$ extraction was achieved between 0.3-0.4 $\mu \mathrm{mol} \mathrm{L}^{-1}$ (Fig. 4).

\subsection{Optimization of volume and ionic liquid amount}

The sample volume as main parameters for $\mathrm{Se}$ extraction based on IICDET ligand and must be optimized at $\mathrm{pH}=4$. So, the different volume of sample urine, blood and serum from 1-20 $\mathrm{mL}$ was used for extraction of Se ions by USADLLMBE procedure as $0.75 \mu \mathrm{g} \mathrm{L}^{-1}$ and $20 \mu \mathrm{g} \mathrm{L}^{-1}$ of selenium (IV). Perfect extraction more than $95 \%$ was achieved by sample volume of $1-10 \mathrm{~mL}$. By increasing of sample volumes, the extraction efficiency was reduced. On the other hand, in high sample volumes, the partially solubilized the ionic liquid phase was increased and decreased accuracy and precision of results. So, a sample volume of $5 \mathrm{~mL}$ was selected as optimum volume for Se(IV) extraction based on ICDET ligand by USA-DLLMBE procedure (Fig. 5). Furthermore, the amount of ionic liquid effected on extraction recovery of $\mathrm{Se}$ in serum, blood, urine samples. Therefore, the different amount of $\left(\left[\mathrm{C}_{8} \mathrm{MIM}\right]\left[\mathrm{PF}_{6}\right]\right.$ as hydrophobic ionic liquid was studied from the range of $0.05-0.35 \mathrm{~g}$. Quantitative extraction was observed at higher than $0.08 \mathrm{~g}$. So, $0.1 \mathrm{~g}$ of 


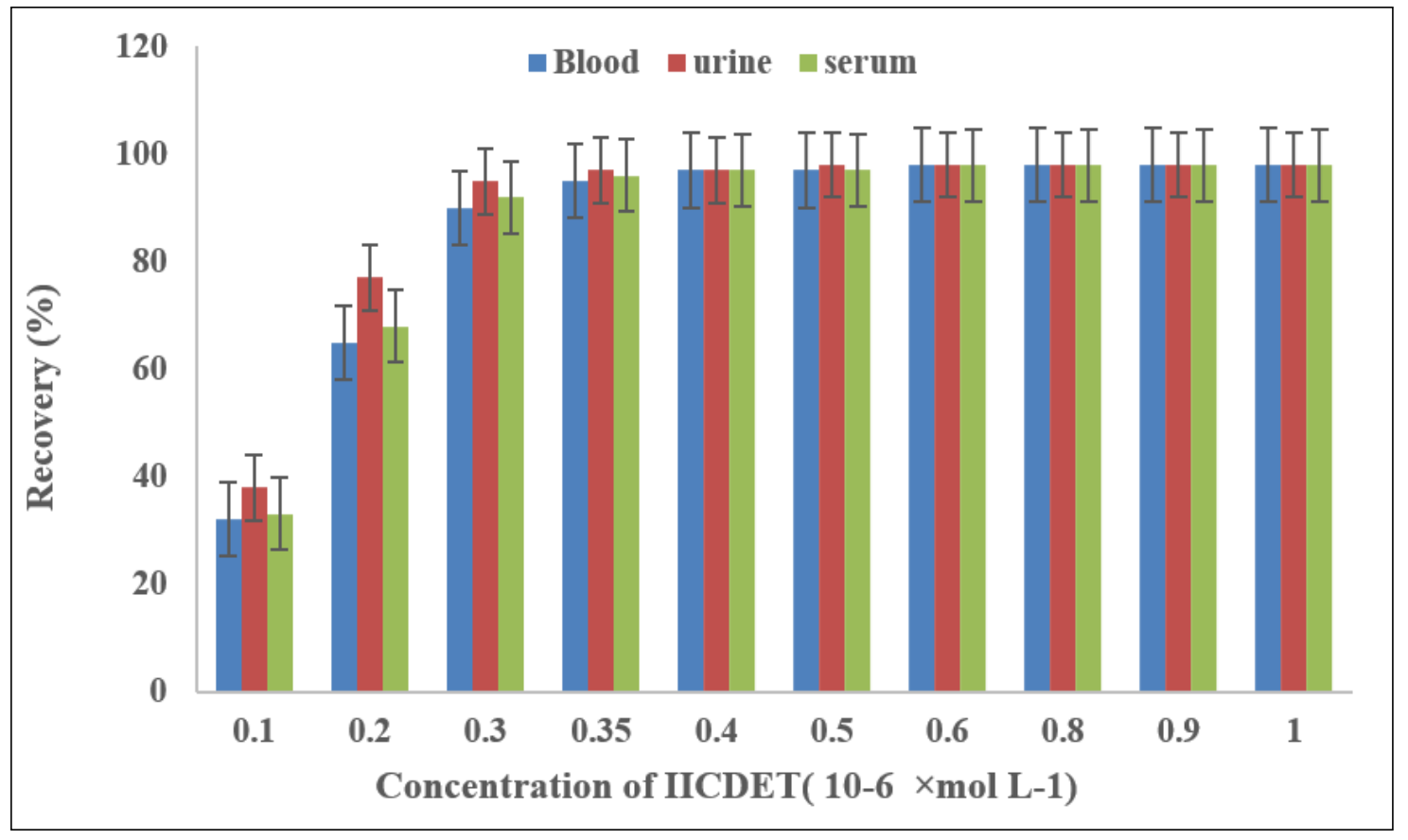

Fig. 4. The effect of IICDET ligand on Extraction Se(IV) by USA-DLLMBE procedure

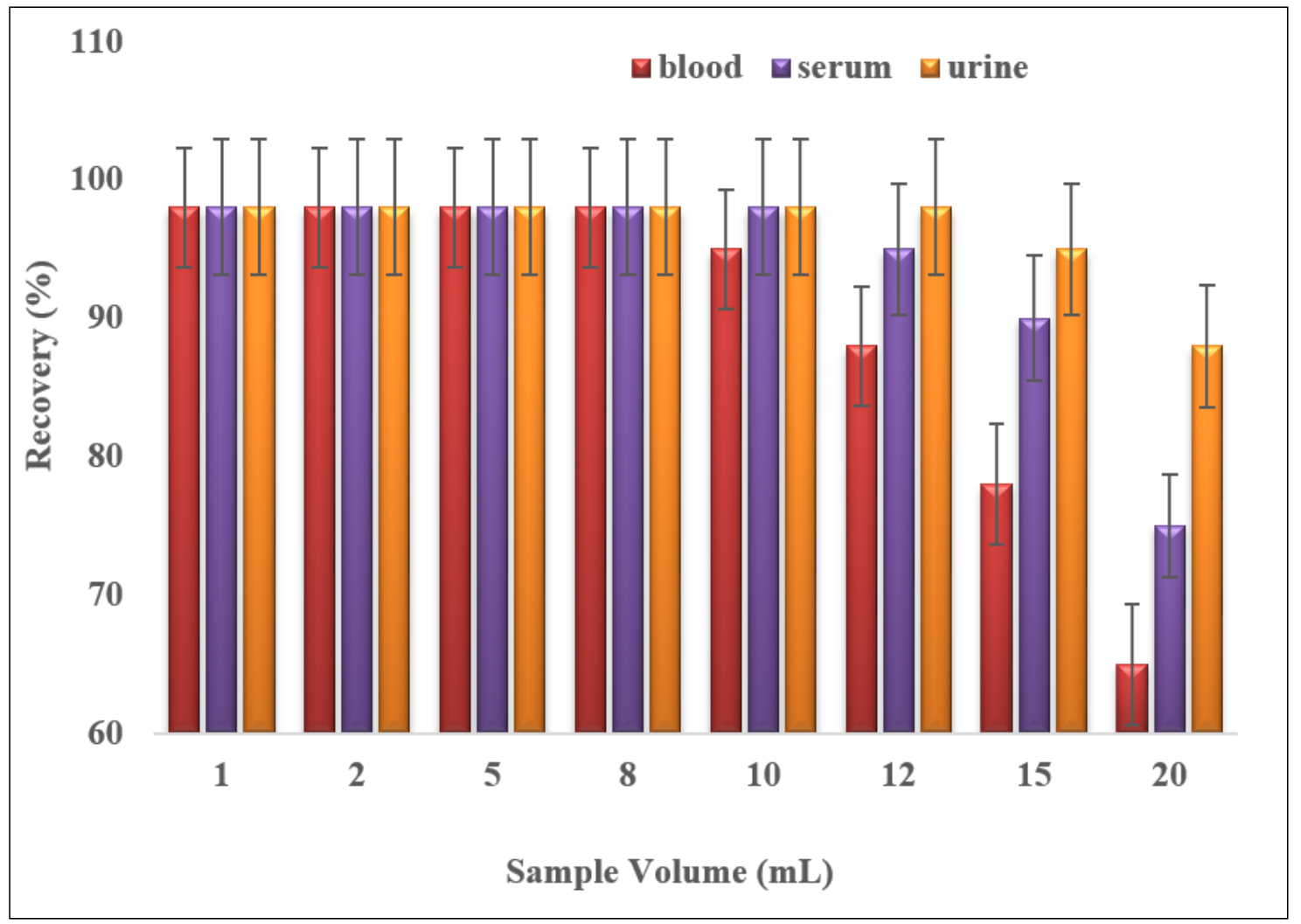

Fig. 5. The effect of sample volume on Extraction Se(IV) by USA-DLLMBE procedure 


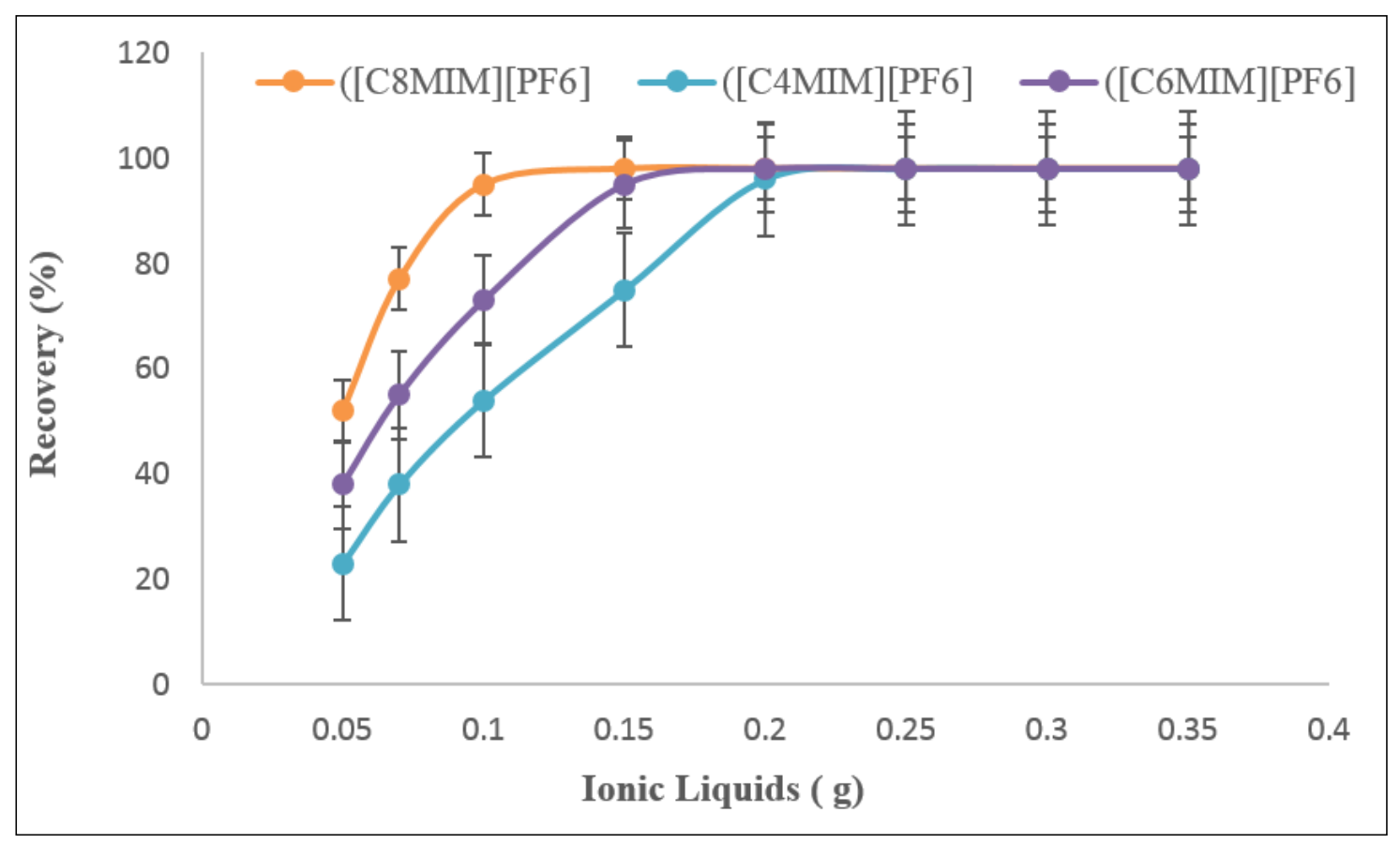

Fig. 6. The effect of amount of ionic liquid on Extraction Se(IV) based on IICDET ligand by USA-DLLMBE procedure

$\left[\mathrm{C}_{8} \mathrm{MIM}\right]\left[\mathrm{PF}_{6}\right]$ was chosen as optimum mass for $\mathrm{Se}$ extraction in $10 \mathrm{~mL}$ of samples at $\mathrm{pH}=4$ (Fig. 6). The results showed, the amounts of IL have changes a little mass in different samples. The amounts of IL for serum, blood and urine samples were obtained $0.09 \mathrm{~g}, 0.1 \mathrm{~g}$ and $0.07 \mathrm{~g}$, respectively.

\subsection{Optimization of Eluent}

The ionic liquids cannot apply directly by ETAAS as a viscose solution with high ash point temperature. So, the se ions were back-extracted from $\left[\mathrm{C}_{8} \mathrm{MIM}\right]\left[\mathrm{PF}_{6}\right]$ by different eluents such as a mineral acidic/basic solution. By changing $\mathrm{pH}$, the complexation of Se-ligand leads to dissociation and Se ions release into the aqueous phase. Therefore, the varying concentration of mineral reagents such as $\mathrm{HCl}, \mathrm{HNO}_{3}, \mathrm{H}_{2} \mathrm{SO}_{4} \mathrm{KOH}$ and $\mathrm{NaOH}$ from $0.5-3$ mol L${ }^{-1}$ were used for Se back-extraction from IL by elution processes (Fig. 7). Based on results, $1.0 \mathrm{~mol} \mathrm{~L}^{-1}$ of $\mathrm{NaOH}$ at $25^{\circ} \mathrm{C}$ can be back-extracted Se (IV) from the IL phase). By procedure, $0.25 \mathrm{~mL}$ of $1.0 \mathrm{~mol} \mathrm{~L}^{-1}$ of $\mathrm{NaOH}$ was added and shacked for I minute at $25{ }^{\circ} \mathrm{C}$. Finally, Se(IV) the remain solution determining by ET-AAS after dilution with DW up to $0.5 \mathrm{~mL}$.

\subsection{Effect of ultrasound and matrix}

By procedure, the different ultrasound times was studied for selenium extraction in urine, blood and serum samples from 30 to 300 seconds. The results showed us, the extraction efficiency of Se improved by increasing the ultra-sonication time and then the relative response increased. Based on results, the maximum extraction was shown at 132 seconds and then remained constant. So, 2.2 minutes was selected as optimum time as ligand complexation (IICDET). Many techniques such as ETAAS have low sensitivity to metal interference ions. Therefore, the most interference ions can be occurred during the pre-concentration or extraction processes which was effected on accuracy of results. So, the important metals based on potential interfering ions for selenium determination were studied and optimized by procedure. $10 \mathrm{~mL}$ sample containing $20 \mu \mathrm{g} \mathrm{L}^{-1}$ of Se and 1-4 $\mathrm{mg} \mathrm{L}^{-1}$ different concentration of matrix ions was used. The tolerate amounts of each ion were tested and results showed the absorbance alteration of interfering metals 


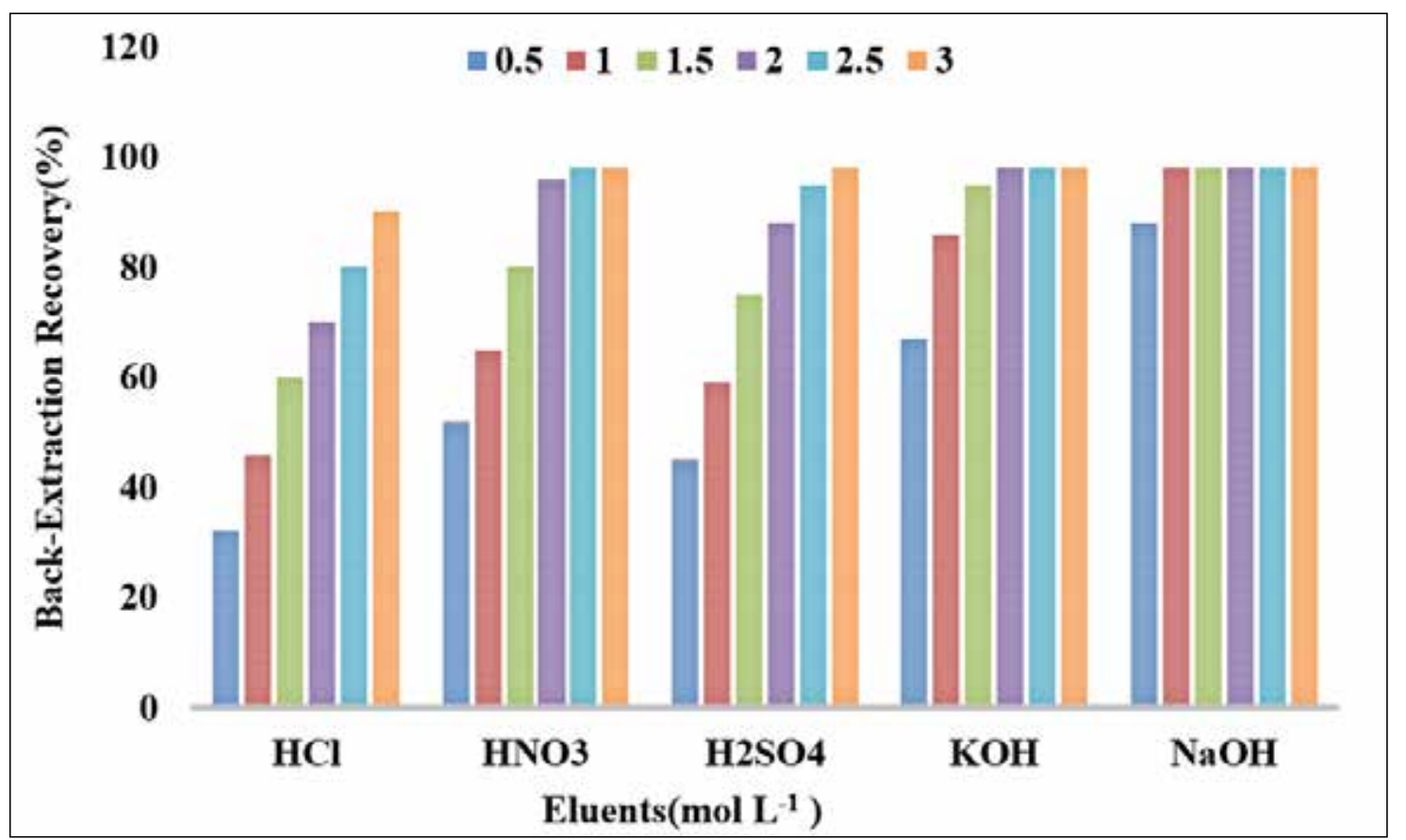

Fig. 7. The effect of different eluents on Extraction Se(VI) based on IICDET ligand by USA-DLLMBE procedure

were less than 5\%. So, the interfering metals don't effected on extraction Se in optimized conditions (Table 1).

\subsection{Analytical features}

Analytical figures of merit were evaluated by USA-DLLMBE procedure for $10 \mathrm{~mL}$ of standard aqueous solutions, serum, urine and blood samples at $\mathrm{pH}=4$ (Table 2). After preconcentration steps, the calibration curve was linear from $0.75-20 \mu \mathrm{g}$ $\mathrm{L}^{-1}$ as a lower limit of quantification (LLOQ) and upper limit of quantification (ULOQ). Detection limits (LOD) and precision (RSD \%) was evaluated for selenium extraction by proposed ligand. The LOD were calculated as the concentration providing an analytical signal three times higher than the background noise. The LOD was obtained $186 \mathrm{ng} \mathrm{L}^{-1}$ and $174 \mathrm{ng} \mathrm{L}^{-1}$ for $10 \mathrm{~mL}$ of human and standard samples, respectively (MLOD $=180$ ng $\mathrm{L}^{-1}$ ). As precision (RSD \%), it was calculated from ten individual standards. The RSD (\%) of Se (IV) in different concentrations of $0.75,1.0$ 5.0, 10, and $20 \mu \mathrm{g} \mathrm{L}^{-1}$ were obtained 3.8, 3.2, 2.7, 2.6 and 2.45, respectively (MRSD\% $=2.95$ ). The enrichment factor (EF), calculated as the ratio of the concentration of Se after preconcentration to that prior preconcentration based on curve fitting calibration rule. The EF of 21.2 and 18.9 for human and standard samples, respectively (M PF=20.1).

\subsection{Validation of Results}

The selenium was extracted and determined in human samples based on IICDET ligand with USA-DLLMBE procedure for $10 \mathrm{~mL}$ of hypothyroidism patients (50) and healthy peoples (50) with aged between 25 - 60 years (Table 3 ). The mean concentration of Se(IV) more than $\mathrm{Se}(\mathrm{VI})$ in human samples and the mean concentration of $\mathrm{Se}(\mathrm{IV})$ and $\mathrm{Se}(\mathrm{VI})$ in hypothyroidism patients lower than healthy peoples. The coloration analysis (r) of total $\mathrm{Se}(\mathrm{IV}$ and VI) in hypothyroidism patients and healthy peoples were less than 0.19 in blood samples. The spiked urine, serum and blood were used to demonstrate the reliability of the method for determination of $\mathrm{Se}(\mathrm{IV})$ and $\mathrm{Se}(\mathrm{VI})$ in hypothyroidism patients by USA-DLLMBE procedure (Table 4). The recovery of spiked samples showed a satisfactorily results with the 
Table 1. The effect of interferences ions on extraction of Se(IV) in human samples by USA-DLLMBE procedure

\begin{tabular}{|c|c|c|}
\hline \multirow[t]{2}{*}{ Blood, Serum (I) } & $\begin{array}{c}\text { Mean ratio } \\
\left(\mathrm{C}_{\mathrm{I}} / \mathrm{C}_{\mathrm{Se}(\mathrm{IV})}\right)\end{array}$ & Recovery (\%) \\
\hline & $\mathrm{Se}(\mathrm{IV})$ & $\mathrm{Se}(\mathrm{IV})$ \\
\hline $\mathrm{Al}^{3+}, \mathrm{Cr}^{3+}$ & 550 & 96.8 \\
\hline $\mathrm{Zn}^{2+}, \mathrm{Cu}^{2+}, \mathrm{Ni}^{2+}, \mathrm{Co}^{2+}, \mathrm{Pb}^{2+}$ & $750-850$ & 97.6 \\
\hline $\mathrm{I}^{-}, \mathrm{Br}^{-}, \mathrm{F}^{-}, \mathrm{Cl}^{-}$ & 1250 & 98.9 \\
\hline $\mathrm{Na}^{+}, \mathrm{K}^{+}, \mathrm{Ca}^{2+}, \mathrm{Mg}^{2+}$ & 1100 & 97.7 \\
\hline $\mathrm{CO}_{3}^{2-}, \mathrm{PO}_{4}^{3-}, \mathrm{NH}_{4}^{+}$ & 950 & 99.3 \\
\hline $\mathrm{Mn}^{2+}, \mathrm{As}^{3+}$ & $150-250$ & $98.1-97.5$ \\
\hline $\mathrm{Cd}^{2+}$ & 200 & 98.4 \\
\hline $\mathrm{Hg}^{2+}$ & 45 & 97.3 \\
\hline \multirow[t]{2}{*}{ Urine (I) } & $\begin{array}{c}\text { Mean ratio } \\
\left(\mathrm{C}_{\mathrm{I}} / \mathrm{C}_{\mathrm{Se}(\mathrm{IV})}\right)\end{array}$ & Recovery (\%) \\
\hline & $\mathrm{Se}(\mathrm{IV})$ & $\mathrm{Se}(\mathrm{IV})$ \\
\hline $\mathrm{Cl}^{-}, \mathrm{NO}_{3}^{-}$ & 1200 & 98.2 \\
\hline $\mathrm{Na}^{+}, \mathrm{K}^{+}$ & 1200 & 98.6 \\
\hline $\mathrm{Ca}^{2+}, \mathrm{Mg}^{2+}$ & 1000 & 98.0 \\
\hline $\mathrm{Zn}^{2+}, \mathrm{Cu}^{2+}$ & 700 & 97.5 \\
\hline $\mathrm{CO}_{3}^{2-}, \mathrm{PO}_{4}^{3--}, \mathrm{NH}_{4}^{+}$ & 900 & 96.9 \\
\hline $\mathrm{Hg}^{2+}$ & 50 & 97.4 \\
\hline $\mathrm{Pb}^{2+}$ & 800 & 98.3 \\
\hline $\mathrm{Ni}^{2+}, \mathrm{Co}^{2+}$ & 700 & 97.2 \\
\hline $\mathrm{Cd}^{2+}$ & 150 & 98.5 \\
\hline $\mathrm{Mn}^{2+}$ & 100 & 96.6 \\
\hline
\end{tabular}

Table 2. The analytical features for selenium determination by USA-DLLMBE procedure

\begin{tabular}{ll}
\hline Features & value \\
\hline Working pH & 4.0 \\
Concentration of IICDET & $0.35 \times 10^{-6} \mathrm{~mol} \mathrm{~L}^{-1}$ \\
Sample volume of Blood, Serum, Urine (mL) & 10.0 \\
Volume of sample injection & $20 \mu \mathrm{L}$ \\
Linear range (Peak Area) & $0.75-20 \mu \mathrm{g} \mathrm{L}^{-1}$ \\
Linear range (Peak Height) & $0.75-10.4 \mu \mathrm{g} \mathrm{L}^{-1}$ \\
Mean RSD \%, $\mathrm{n}=10$ & 2.95 \\
LOD for human sample & $0.187 \mu \mathrm{g} \mathrm{L}^{-1}$ \\
LOD for standard sample & $0.174 \mu \mathrm{g} \mathrm{L}^{-1}$ \\
Enrichment factor for human blood or serum & 21.2 \\
Enrichment factor for standard & 18.9 \\
Volume and concentration of NaOH & $0.25 \mathrm{~mL}, 1 \mathrm{M}$ \\
Shaking/Centrifuging time & $2.2 \mathrm{~min}, 3.0 \mathrm{~min}$ \\
Correlation coefficient & $\mathrm{R}^{2}=0.9997$ \\
\hline
\end{tabular}


ability of procedure for determination of $\mathrm{Se}(\mathrm{IV})$ and $\mathrm{Se}(\mathrm{VI})$ in hypothyroidism patients. Furthermore, the real blood, serum and urine samples were analyzed with ICP-MS and used as a CRM by USA-DLLMBE procedure. The results showed, the favorite efficiency and reliability of proposed method for determination and speciation of Se(IV) and $\mathrm{Se}(\mathrm{VI})$ in hypothyroidism patients (Table 5).

\section{Conclusions}

A simple and efficient method based on IICDET ligand was used for the speciation and determination of trace amount of $\mathrm{Se}(\mathrm{IV})$ and $\mathrm{Se}$ (VI) in hypothyroidism patients by USADLLMBE procedure coupled to ET-AAS. The main parameters such as sample volume, $\mathrm{pH}$ and ligand amount were optimized. This procedure introduced a sensitive, efficient and low cost method for speciation and separation of the $\mathrm{Se}(\mathrm{IV})$ and $\mathrm{Se}(\mathrm{VI})$ in human biological samples. The performance of USA-DLLMBE procedure for quantification extraction of $\mathrm{Se}(\mathrm{IV})$ and $\mathrm{Se}(\mathrm{VI})$ in blood, urine and serum samples was satisfactory. The favorite LOD, LOQ and RSD\% achieved 0.18, 0.75 and 2.95 , respectively and are comparable to previous reported methods. Based on results, the selenium concentration in thyroid patients was decreased as compared to healthy peoples. The method was validated by certified reference material (CRM) and ICP-MS analysis in real samples.

Table 3. Speciation and determination of $\mathrm{Se}(\mathrm{IV})$ and $\mathrm{Se}(\mathrm{VI})$ in serum, blood and urine samples based on IICDET ligand by USA-DLLMBE procedure (Serum and blood: $\mu \mathrm{gL}^{-1}$, Urine: $\mu \mathrm{g} \mathrm{g}^{-1}$ )

\begin{tabular}{lllllll|}
\hline \multirow{2}{*}{ Sample } & \multicolumn{2}{c}{ Patients $(\mathbf{n}=\mathbf{5 0})$} & \multicolumn{2}{c}{ Healthy peoples $(\mathbf{n = 5 0 )}$} & \multicolumn{2}{c|}{ Patients /healthy } \\
\cline { 2 - 8 } & $\mathbf{S e}(\mathbf{I V})$ & $\mathbf{S e}(\mathbf{V I})$ & $\mathbf{S e}(\mathbf{I V})$ & $\mathbf{S e}(\mathbf{V I})$ & $\mathbf{r}$ & P value \\
\hline Serum & $77.9 \pm 11.9$ & $16.8 \pm 4.8$ & $130.7 \pm 21.7$ & $21.8 \pm 4.3$ & 0.202 & $<0.001$ \\
Urine & $14.5 \pm 3.7$ & $2.7 \pm 0.9$ & $22.7 \pm 7.8$ & $3.6 \pm 0.8$ & 0.187 & $<0.001$ \\
Whole Blood & $81.8 \pm 13.8$ & $17.4 \pm 5.6$ & $122.4 \pm 18.6$ & $34.5 \pm 6.6$ & 0.194 & $<0.001$ \\
\hline
\end{tabular}

*Correlations are based on Pearson coefficients (r). Statistical significance will be observed if $P<0.05$ Mean of three determinations of samples \pm standard deviation $(\mathrm{P}=0.95, \mathrm{n}=10)$

Table 4. Analytical results of $\mathrm{Se}(\mathrm{IV}), \mathrm{Se}(\mathrm{VI})$ and T-Se determination in serum, blood and urine samples with USA-DLLMBE procedure and ICP-MS $\left(\mu \mathrm{g} \mathrm{L}^{-1}\right)$

\begin{tabular}{|c|c|c|c|c|c|c|c|c|c|}
\hline \multirow{2}{*}{ Sample } & \multicolumn{2}{|c|}{ Added_ } & \multicolumn{2}{|c|}{${ }^{*}$ Found $\left(\mu g \mathbf{L}^{-1}\right)$} & \multicolumn{2}{|c|}{ * ICP-Ms } & \multicolumn{2}{|c|}{ Recovery (\%) } & \multirow[b]{2}{*}{ T-Se } \\
\hline & $\operatorname{Se}(I V)$ & $\operatorname{Se}(V I)$ & $\mathrm{Se}(\mathrm{IV})$ & $\mathrm{Se}(\mathrm{VI})$ & T-Se & T-Se & $\operatorname{Se}(I V)$ & $\mathrm{Se}(\mathrm{VI})$ & \\
\hline \multirow{3}{*}{ Blood } & ----- & ----- & $67.5 \pm 3.3$ & $12.8 \pm 0.6$ & $80.3 \pm 4.2$ & $79.2 \pm 2.7$ & ---- & ---- & ---- \\
\hline & 50 & ----- & $115.3 \pm 5.6$ & $12.6 \pm 0.5$ & $127.6 \pm 6.1$ & $129.3 \pm 3.5$ & 95.6 & ----- & 94.6 \\
\hline & ----- & 10 & $67.3 \pm 3.4$ & $22.7 \pm 1.1$ & $90.0 \pm 4.7$ & $88.8 \pm 2.9$ & ----- & 99.0 & 97.0 \\
\hline \multirow{3}{*}{ Serum } & ----- & ----- & $81.6 \pm 3.8$ & $17.5 \pm 0.8$ & $99.1 \pm 5.1$ & $100.3 \pm 3.4$ & ----- & ----- & ---- \\
\hline & 100 & ----- & $180.2 \pm 8.5$ & $17.2 \pm 0.7$ & $197.4 \pm 9.3$ & $195.6 \pm 5.8$ & 98.6 & ----- & 98.3 \\
\hline & ----- & 20 & $82.2 \pm 4.2$ & $37.2 \pm 1.8$ & $119.4 \pm 5.5$ & $120.5 \pm 3.6$ & ----- & 98.5 & 101.5 \\
\hline \multirow{3}{*}{ Urine } & ----- & ----- & $12.6 \pm 0.6$ & $3.8 \pm 0.2$ & $16.4 \pm 0.8$ & $15.8 \pm 0.3$ & ----- & ----- & ----- \\
\hline & 10 & ----- & $22.4 \pm 1.2$ & $3.7 \pm 0.2$ & $26.1 \pm 1.3$ & $26.5 \pm 0.5$ & 98.0 & ----- & 97.0 \\
\hline & ----- & 5 & $12.7 \pm 0.6$ & $8.6 \pm 0.4$ & $21.3 \pm 1.1$ & $20.8 \pm 0.6$ & ----- & 96.0 & 98.0 \\
\hline
\end{tabular}

\footnotetext{
* Mean of three determinations \pm standard deviation $(\mathrm{P}=0.95, \mathrm{n}=5)$
}

All blood and serum samples diluted with DW (1: 10) 
Table 5. Validation of methodology for determination selenium based on certified reference material (CRM) by USA-DLLMBE procedure

\begin{tabular}{lcccc}
\hline Sample & Certified $\left(\boldsymbol{\mu g} \mathbf{L}^{-1}\right)$ & Added $\left(\boldsymbol{\mu g} \mathbf{L}^{-1}\right)$ & ${ }^{*}$ Found $\left(\boldsymbol{\mu g} \mathbf{L}^{-1}\right)$ & Recovery $(\mathbf{\%})$ \\
\hline CRM1598a & $13.44 \pm 0.58$ & 10 & $23.22 \pm 1.14$ & 97.8 \\
\hline S-ICP-MS & $15.56 \pm 0.46$ & 10 & $25.13 \pm 1.23$ & 95.7 \\
\hline
\end{tabular}

* Mean of three determinations \pm standard deviation $(\mathrm{P}=0.95, \mathrm{n}=5)$

All blood and serum samples diluted with DW (1: 10)

CRM1598a selenium in animal serum

S-ICP-MS: Human serum analyses with ICP-MS

\section{Acknowledgment}

The authors wish to thank from Department of Medical Nanotechnology, Faculty of Advanced Sciences and Technology, Tehran Medical Sciences, Islamic Azad University, (project NS: 960250673) Tehran, Iran, the Iranian Research Institute of Petroleum Industry (RIPI) for supporting of this work.

\section{References}

[1] G. Bjørklund, J. Aaseth, A.V. Skalny, J. Suliburska, M.G. Skalnaya, A.A. Nikonorov, Interactions of iron with manganese, zinc, chromium, and selenium as related to prophylaxis and treatment of iron deficiency, J. Trace Elem. Med. Biol., 41(2017) 41-53.

[2] M. Kucharzewski, J. Braziewicz, U. Majewska, S. Góźdź, Concentration of selenium in the whole blood and the thyroid tissue of patients with various thyroid diseases, Biol. Trace Elem. Res., 88 (2002) 25-30.

[3] M.K. Gürgöze, A. Olçücü, A.D. Aygün, E. Taskin, M. Kiliç, Serum and hair levels of zinc, selenium, iron, and copper in children with iron-deficiency anemia, Biol. Trace Elem. Res., 111 (2006) 23-29.

[4] W. Chin-Thin, C. Wei-Tun, P. Tzu-Ming, W. Ren-Tse, Blood concentrations of selenium, zinc, iron, copper and calcium in patients with hepatocellular carcinoma, Clin. Chem. Lab. Med., 40 (2002) 1118-1122.

[5] A.K. Baltaci, R. Mogulkoc, M. Belviranli, Serum levels of calcium, selenium, magnesium, phosphorus, chromium, copper and iron--their relation to zinc in rats with induced hypothyroidism, Acta Clin. Croat., 52 (2013) 151- 156.

[6] G.F. Combs, Biomarkers of selenium status, Nutrients., 7 (2015) 2209-36

[7] P.P. Felix, E.L. Ander, Urine selenium concentration is a useful biomarker for assessing population level selenium status, Environ. Int., 134 (2020) 105218.

[8] D.L. Hatfield, P.A. Tsuji, B.A. Carlson, V.N. Gladyshev, Selenium and selenocysteine: Roles in cancer, health, and development, Trends Biochem. Sci., 39 (2014) 112-20.

[9] W. Yang, A.M. Diamond, Selenium-binding protein as a tumor suppressor and a prognostic indicator of clinical outcome, Biomark Res., 1 (2013) 15.

[10] Y. Wang, W. Fang, Y. Huang, F. Hu, Q. Ying, W. Yang, B. Xiong, Reduction of selenium-binding protein 1 sensitizes cancer cells to selenite via elevating extracellular glutathione: a novel mechanism of cancerspecific cytotoxicity of selenite, Free Radic. Biol. Med., 79 (2015) 186-196.

[11] S. Misra, R.W. Kwong, S. Niyogi, Transport of selenium across the plasma membrane of primary hepatocytes and enterocytes of rainbow trout, J. Exp. Biol., 215 (2012) 1491-501.

[12] Z. Huang, A.H. Rose, P.R. Hoffmann, The role of selenium in inflammation and immunity: from molecular mechanisms to therapeutic opportunities, Antioxid Redox 
Sign. 16 (2012) 705-743

[13] N. Manevska, S. Stojanoski, T. Makazlieva, Selenium treatment effect in auto-immune hashimoto thyroiditis in macedonian population, J. Endocrinol. Metabol., 9 (2019) 22-28.

[14] M. Leo, L. Bartalena., G. Rotondo Dottore, Effects of selenium on short-term control of hyperthyroidism due to Graves' disease treated wif methimazole: results of a randomized clinical trial, J. Endocrinol. Invest., 40 (2017) 281-287.

[15] G. Ira Martin, R. James, Sowers thyroid and the heart, Am. J. Med., 127 (2014) 691-698.

[16] M. Outzen, A. Tjonneland, E.H. Larsen, S. Friis, S.B. Larsen, J. Christensen, Selenium status and risk of prostate cancer in a Danish population, Brit. J. Nutr., 115 (2016) 1669-77.

[17] A. Dalia, T. Loh, A. Sazili, M. Jahromi, A. Samsudin, The effect of dietary bacterial organic selenium on growth performance, antioxidant capacity, and selenoproteins gene expression in broiler chickens, BMC Vet. Res., 13 (2017). http://doi:10.1186/s12917017-1159-4.

[18] S.S. Najim, Determination of some trace elements in breast cancer serum by atomic absorption spectroscopy, Int. J. Chem., 9 (2017) 1-6.

[19] M. Krawczyk-Coda, Determination of selenium in food samples by high-resolution continuum source atomic absorption spectrometry after preconcentration on halloysite nanotubes using ultrasound-assisted dispersive micro solid-phase extraction, Food Anal. Meth., 12 (2019) 128-135.

[20] A. Terol, F. Ardini, A. Basso, M. Grotti, Determination of selenium urinary metabolites by high temperature liquid chromatography-inductively coupled plasma mass spectrometry, J. Chromatogr., 1380 (2015) 112-119.

[21] K. Pyrzynska, A. Sentkowska, Liquid chromatographic analysis of selenium species in plant materials, TrAC, Trend Anal. Chem., 111 (2019) 128-138.
[22] C.K Su, W.C. Chen, 3D-printed, $\mathrm{TiO}_{2} \mathrm{NP}-$ incorporated minicolumn coupled with ICP-MS for speciation of inorganic arsenic and selenium in high-salt-content samples, Microchim. Acta., 185 (2018) 1-8.

[23] M. Pettine, T.J. McDonald, M. Sohn, G.A.K. Anquandah, R. Zboril, V.K.A Sharma, Critical review of selenium analysis in natural water samples, Trends Environ. Anal., 5 (2015) $1-7$.

[24] T. Hu, L.P. Liu, S.Z. Chen, W.L. Wu, G.G. Xiang, Y.B. Guo, Determination of selenium species in cordyceps militaris by highperformance liquid chromatography coupled to hydride generation atomic fluorescence spectrometry, Anal. Lett., 51 (2018) 23162330.

[25] A.S.A. Ibrahim, R. Al-Farawati, U. Hawas,Y, Shaban, Recent microextraction techniques for determination and chemical speciation of selenium, Open Chem., 15 (2017) 103-122.

[26] L. Nyaba, J.M. Matong, K.M. Dimpe, P.N. Nomngongo, Speciation of inorganic selenium in environmental samples after suspended dispersive solid phase microextraction combined with inductively coupled plasma spectrometric determination, Talanta., 159 (2016) 174-180.

[27] A.H. Panhwar; M. Tuzen, T.G. Kazi, Ultrasonic assisted dispersive liquid-liquid microextraction method based on deep eutectic solvent for speciation, preconcentration and determination of selenium species (IV) and (VI) in water and food samples, Talanta, 175 (2017) 352-358.

[28] N. Motakef Kazemi, A novel sorbent based on metal-organic framework for mercury separation from human serum samples by ultrasound assisted- ionic liquid-solid phase microextraction, Anal. Methods Environ. Chem. J., 2 (2019) 67-78. 